\title{
Remittances and development: Zimbabwean migrant teachers in South Africa and their impact on their Zimbabwean families
}

\author{
Inocent Moyo ${ }^{1}$ and M D Nicolau ${ }^{2}$ \\ ${ }^{1}$ Department of Geography, \\ ${ }^{2}$ Director, School of Environmental Sciences \\ University of South Africa \\ Florida Campus, Private Bag X6, Florida, \\ South Africa1710 \\ minnoxa@yahoo.com
}

\begin{abstract}
This paper contends that the unprecedented migration of Zimbabwean teachers into South Africa has transformed the well-being of their families in Zimbabwe positively. In some cases, poverty at household level has even been alleviated as a result of remittances sent to Zimbabwean households of the Zimbabwean teachers in South Africa. On the strength of human development impacts such as increased household income and consumption, savings and asset accumulation, improved access to health and nutrition and access to better education identified in this research, it is possible to hypothesize that professional Zimbabwean migrant teachers in South Africa who maintain ties with their home country do indeed make a positive contribution to their own families' and households' human development needs back home in Zimbabwe.
\end{abstract}

Keywords: Zimbabwean migrant teachers, poverty, migrant families, households, human development

\section{Introduction}

The migration of people from many countries to South Africa is not a new phenomenon. The movement of both professional and unskilled workers to South Africa has been taking place since the late $19^{\text {th }}$ century (Crush et al., 2005; Oucho, 2005). During the apartheid era, black migrants to South Africa came predominantly from the surrounding countries and worked on white farms, various manufacturing industries but especially on the mines located in the geological area of the Witwatersrand (Jevees, 1985). As a result of the democratic dispensation in South Africa in 1994, there was a related increase in the migration of people from all African countries and particularly the Southern African region into South Africa (World Migration Report, 2000; Adepoju, 2003; Campbell, 2006). This movement of people took place against the background that South Africa was perceived by many African migrants as a destination of tranquillity, an economic haven and a place of prosperity on the African continent that was otherwise gripped by, inter alia, political and economic turmoil and paralysis (De La Hunt, 1998; Miles, 1998; Manghezi, 1998; World Migration Report, 2000; Adepoju, 2003; Crush et al., 2006; Crush and Pendleton, 2007).
Although the South African democratic dispensation led to an increase in the influx of immigrants, this should, however, be seen within the context that the country's immigration policies after 1994, did not encourage a deliberate import of labour into South Africa. According to Crush and McDonald (200I) and Crush et al. (2006), there was a belief that a deliberate policy to encourage immigration and the import of labour would threaten the interests of the newly acquired political status of the country that sought to ensure equality and equity for its citizens. This was occurring at a time when many professionals in South Africa in the 1990s, and also later on, began to look for employment in countries in North America, Europe, New Zealand and Australia (Crush 2002). Nevertheless, since the year 2000, the South African government realized that it could not contain its own skills brain drain which led to a more open immigration policy with supporting laws (Crush et al., 2006).

The loss of a number of professionals including teachers, created a gap in the human resource pool in South Africa that needed to be filled to ensure the economic prosperity of the country. Govender (2008) notes that 94000 teachers were urgently 
required in South Africa and also refers to the release of a report by the Organization for Economic Corporation and Development (OECD) that was commissioned by the South African Department of Education. Here it is stated that, of the 20000 teachers who were required annually, only 6000 of them were qualified, and only 4000 actually took up teaching as a profession. The report further records that, of the 433280 teaching posts in South African schools, 62612 were not filled by the end of May 2008, and 31 949 were staffed by under-qualified and temporary teachers. Furthermore, Davids (2009) mentions that a third of South African teachers lack the appropriate qualifications. This has resulted in a severe shortage of skills in this area of employment.

The shortage of teachers in South Africa created an opportunity for Zimbabwean teachers who had migrated to South Africa because of worsening economic and political condition in their country (Crush et al., 2005). Against this background, the question arises: Since the Zimbabwean teachers are now working in an economically stable country, to what extent has the gainful employment transformed their families and households in Zimbabwe? In an attempt to establish an answer to this question, this paper focuses on the development impacts that the migrant teachers have on their families who stay in Zimbabwe. The question is pertinent because the results from the investigation of the development impact of remittances in migrant sending areas suggest that Zimbabwean migrant teachers came to South Africa because they wanted to improve their own lives and those of their family members directly or indirectly dependent on them. In this paper 'development' is understood to refer to the improvement in human welfare, particularly in the lives of migrants themselves and the people who rely on them for their material well-being. The development impact of migration should be understood within the context of personal remittances that the migrants send back home and, as noted by Pendleton et al. (2006), these include both money and different types of goods.

\section{Theoretical perspectives}

We locate this paper within the debates around the migration-remittances-development nexus. This is because there is no agreement on the development impact of remittances. There are generally two opposing schools of thought regarding the development impact of remittances that the migrant workers send to their home countries. The first one is the developmentalist perspectives that emphasize that remittances promote development (Chimhowu et al., 2005; Sander and Maimbo, 2005; Omar and
Koury, 2005; Kapur, 2005). The second is referred to as the migrant syndrome perspectives that points out that remittances are not put to good use and do not bring about development (Keeley, 1989; Gammeloft and Taylor as cited in Chimhowu et al., 2005). The latter supports arguments by Zachariah (cited in De Haas, 2008) that remittances do not lead to development but increase inter-personal inequalities. Lipton (1982) further argues that remittances are not spent on productive investment but promote consumerist attitudes which do not bring about effective development.

Furthermore, there is on-going debate on the development impact of remittances from the SouthSouth migration perspective (Ratha and Shaw, 2007a, 2007b). Studies in several sub-Saharan countries by Maimbo and Ratha (2005); Chami and Samir (2005); Pendleton et al. (2006) have demonstrated this phenomenon and Zimbabwe has not escaped this focus. For example, Burgsdorff (2012) records that total remittance flows from South Africa to Zimbabwe amounted to R 5.I-6.8 billion in 20II. Maphosa $(2005,2007,2009)$ has shown that in the southern districts of Zimbabwe, remittances are used for consumption, buying livestock, construction of houses and development of rural based general dealer business shops. Ncube and Gomez (20II) have shown that in Ward 2, Tsholotsho district in south-western Zimbabwe, remittances are largely used for household consumption and meeting the financial needs of family members. This consumerist behaviour has facilitated the development of business shops so as to meet the purchasing power of the remittance receiving household members with available cash. This suggests a development impact. Both Tevera and Chikanda (2009) and Von Burgsdorff (2012) observe that international remittances have significant development impacts, the latter scholar referring to Zimbabwe in particular.

The debate on the development impact of remittances in Zimbabwe is clearly on-going. This paper contributes to the discussion by focusing on the impact of remittances sent by professional Zimbabwean migrant teachers working in South Africa to their families still living in Zimbabwe. The approach adopted compares the pre-migration circumstances with how life changed for the families of Zimbabwean teachers after migration had occurred. The emphasis is on human development with regard to what changed and to what extent. This is necessary so as to extend the debate on the development impact of remittances on sending regions like Zimbabwe, especially given the fact that many migrants continue to work outside their country and also that there is no consensus on the development impact of remittances. 


\section{Methodology}

In attempting to understand the development impact that the Zimbabwean migrant teachers have had on their families in Zimbabwe, a mixed methods approach was adopted for an investigation into this issue conducted between July and December 2009. This mixed method approach is a recommended procedure that combines quantitative and qualitative research methods (Creswell, 2009; Tashakkori and Teddlie, 2003; Teddlie and Tashakkori, 2009; Creswell and Plano Clark, 20I I). Justification for this, is based on the assumption that their complementarity enhances the results of a study unlike the case in which only one method is used (Creswell and Plano Clark, 2007). This broadens the understanding of the phenomenon under study (Creswell, 2009). Such methodological pluralism allows for greater insight into social reality as a concept, enabling different facets of the problem to be explored (Bloor, 1997; Creswell and Plano Clark, 2007; Creswell, 1994, 2009). The quantitative technique of collecting data involved the administration of a questionnaire using a sample of 63 Zimbabwean migrant teachers in Johannesburg's inner city. The sample was drawn from nine (9) schools in the area that had a combined teacher population of about 180 . The snowball sampling technique was used to distribute the questionnaires. Remittances can be analysed at different levels, for example, at household, community, national and international levels (Chimhowu et al., 2005). Since the focus of the development impact of migration in this paper is at household level, the areas of attention are: household income and consumption (Kannan and Hari as cited in Chimhowu et al., 2005); savings and asset accumulation (Hadi, Lucas and Stark as cited in Chimhowu et al., 2005); improved access to health services and better nutrition (Yang, as cited in Chimhowu et al., 2005); and access to better education (Edwards and Ureta, as cited in Chimhowu et al., 2005). The questionnaire survey elicited information on these issues from a sample of Zimbabwean teachers.

In addition to the questionnaire survey, in-depth qualitative interviews were also done with nine Zimbabwean migrant teachers to augment the questionnaire survey and obtain deeper understanding of the development impact of the Zimbabwean migrant teachers on their families and households in Zimbabwe. In an attempt to achieve a fair representation in the selection of interviewees, one teacher from each of the nine schools was interviewed. Questionnaire results were analysed using Microsoft Excel to generate descriptive statistics. In-depth interview results were first analysed manually by transcribing the interviews and reading through the transcriptions. A descriptive write-up followed leading to identification and classification of emerging themes and the establishment of connections and explanations. This method of analysing qualitative data is recommended by Dey (1995 as cited in Kitchen and Tate, 2000; Creswell, 2009).

\section{Limitations of the study}

The administration of questionnaires for selfreporting by the Zimbabwean migrant teachers had potential limitations. It was possible that they would answer questions projecting themselves in a positive way, just to justify that coming to South Africa was the best decision possible for them. It was not feasible to physically verify all their claims about their achievements such as houses built, or in the process of being built, access to better education facilities, health and improvements is nutrition. This can affect the accuracy and validity of conclusions drawn from such data, as it can be influenced by the respondent's motivation, expectations or assumptions. However, in this case the deployment of the qualitative technique was intended to mitigate possible inherent limitations in the sense that the life stories from the in-depth interviews were expected to yield more meaningul and deeper information. The findings are therefore to be seen as context specific and therefore not generalizable. Despite the suggested limitations, the study demonstrates, in the following discussion, the development impact of remittances on the households of remittance - receiving families.

\section{Household income and consumption}

The typical migrant Zimbabwean teacher is a male (7I per cent in the sample that illustrates this dominant characteristic) in the $3 \mathrm{I}-40$ year old age group. The majority ( 89 per cent in the sample) had children and an extended family that stayed in Zimbabwe permanently. These migrant teachers come from all parts of Zimbabwe both urban and rural, and their teaching in South Africa was their main source of income. The sample data (Figure I) shows that a striking majority of the migrant teachers earned between R4 00I-R6 000 per month in 2009 with an even spread between those earning somewhat more (over R6 000 monthly) and somewhat less (R2 000-R4 000) with a smaller group being paid RIO 000 per month and more. Overall a lower rate of pay is implied in comparison to the salaries paid in the public sector. 
Figure I: Salary distribution of Zimbabwean migrant teachers

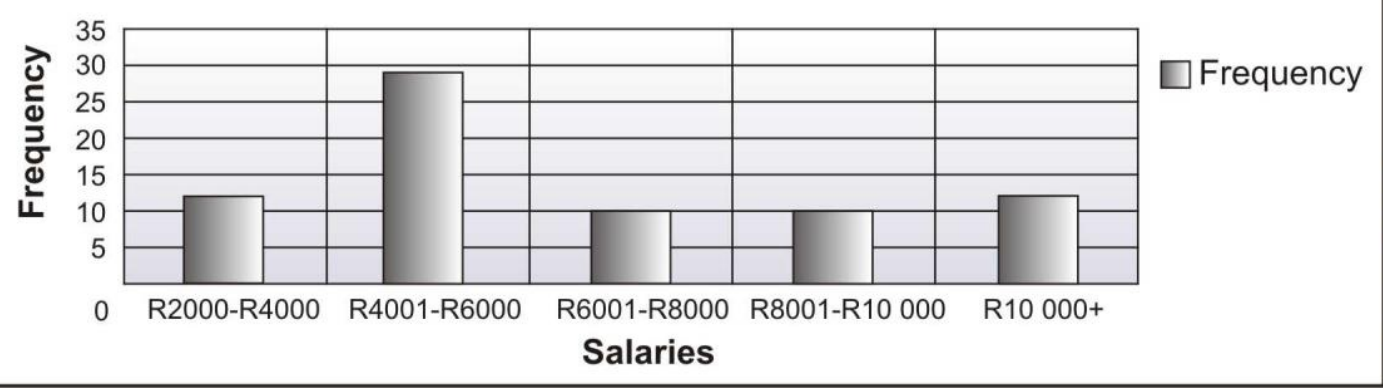

It was from these salaries that the migrant teachers frequently sent money to Zimbabwe. The pattern of depth interviews that these were very recent migrant sending money, as depicted in Figure 2, is that the teachers who received low salaries) to Zimbabwe. majority sent monthly, followed by those who send quarterly and then 6 monthly showing their commitment to regular smaller payments. A small group never sent anything (it emerged during the in -

Figure 2: Frequency of money remittances to Zimbabwe

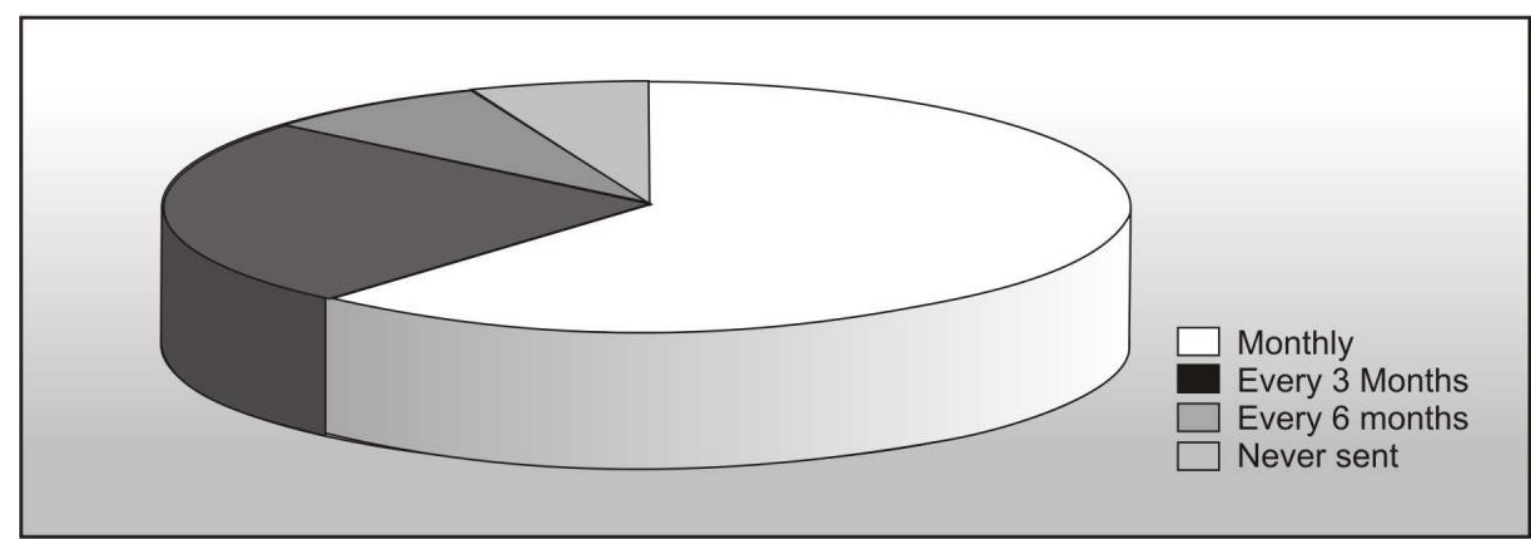

Figure 3 show that, considering their income, the Zimbabwean migrant teachers sent substantial amounts of money to their families in Zimbabwe. Based on the frequency of remitting money to
Zimbabwe (Figure 2) and the amount of money that was sent back to Zimbabwe, it was evident that the majority of the families linked to the respondents always had cash.

Figure 3: Amounts of money remittances sent to Zimbabwe

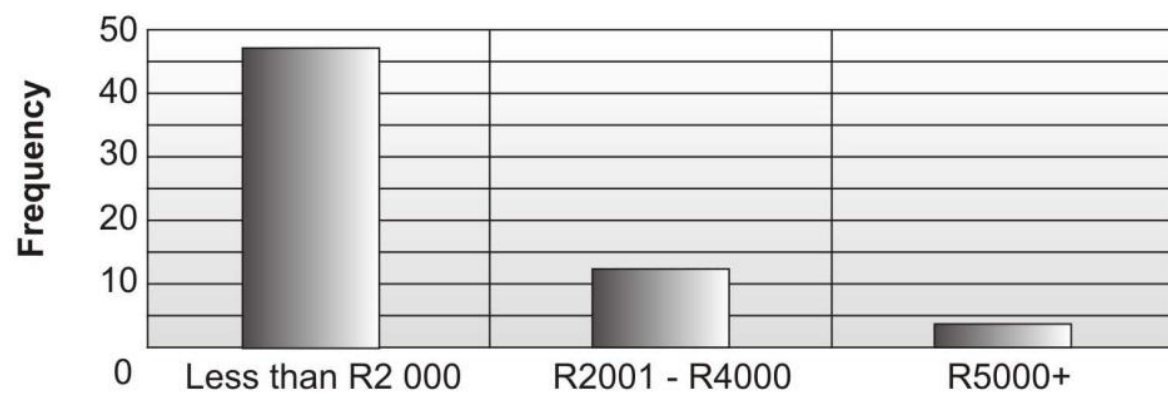

Amounts 
This is especially noteworthy given the fact that over and above the money that was remitted, the Zimbabwean migrant teachers also sent a variety of goods such as food (the availability of different types of food items improved and increased the levels of consumption given the fact that before migration, there were acute food shortages and in some cases starvation), electrical items, toiletries and any other items that were needed by their families (Table I)

Table I: Goods sent to Zimbabwe by migrant teachers.

\begin{tabular}{|l|l|}
\hline Type of goods sent to Zimbabwe & Number \\
\hline Food & 18 \\
\hline Electrical & 11 \\
\hline Clothes & 10 \\
\hline Furniture & 6 \\
\hline What is needed & 5 \\
\hline Toiletries & 5 \\
\hline Other & 5 \\
\hline Never sent & 3 \\
\hline Total & 63 \\
\hline
\end{tabular}

The effect of this is that the families in Zimbabwe were able to save some of the money as well as having it available to pay school fees (once a term of which a term is four months), transport to and from school and buying bread and milk for daily needs. This suggests an improvement in household incomes on account of the fact that, when the migrant teachers were in Zimbabwe, they did not have an adequate disposable income nor did they have cash available on each of the thirty days in a month. Their migration to South Africa changed this negative situation. Since their migration to South Africa, their families in Zimbabwe always have money to meet their basic and daily needs thereby creating a new world from what they were used to before their migration to the south.

\section{Savings and asset accumulation}

Different migrants had achieved different things since coming to South Africa. Most migrant teachers now own or are in the process of building a house in Zimbabwe, affording their families comfortable living conditions. Possibly, this could be explained by the relatively better salaries that they received here in South Africa as compared to what they were earning in Zimbabwe at the time of their migration. In 2009, teachers in Zimbabwe were paid US\$155 (Sibanda,
2009), which is about RI 200 at the exchange rate at the time. In January 2012 Zimbabwean teachers were paid an average of US $\$ 300$ (Mavhunga, 20I2), which at the exchange rate of that time was about R2 550 . This implies that the migrant teachers were relatively better off because, while in South Africa, they can afford to remit both goods and money to Zimbabwe.

In addition, the migrant teachers have been able to acquire specific various assets (Table 2). It is clear that, on the strength of working in South Africa, there has been an improvement in asset accumulation. The houses that are being constructed or have been bought are in Zimbabwe and are used by the families of the migrant teachers. The teachers revealed that working in South Africa has enabled them to buy a variety of assets that they never dreamt of having while they were in Zimbabwe. The researcher was not able to view these acquisitions physically except the cars. Nevertheless, it can be concluded in general that the assets like houses that have been bought in Zimbabwe, or are being constructed in Zimbabwe, and those movable assets that have been bought in South Africa and transported to Zimbabwe, would have improved the welfare of the families of these migrant teachers. 
Table 2: Assets acquired by migrant teachers (Movable assets acquired in South Africa and sent to Zimbabwe, immovable assets bought in Zimbabwe using remittances).

\begin{tabular}{|l|l|}
\hline Assets acquired & Number \\
\hline Nothing & 16 \\
\hline House & 15 \\
\hline Furniture and electrical goods & 11 \\
\hline Process of building a house & 10 \\
\hline Car & 6 \\
\hline Other & 1 \\
\hline Total & 63 \\
\hline
\end{tabular}

The research undertaken for this paper suggests that, in terms of asset accumulation, remittances do indeed play a positive role in improving living conditions. On the strength of the money that the migrants send home, they have built houses in Zimbabwe and some are in the process of doing so. Indeed, this was only possible because of the access to money, which migrant teachers earned while working in South Africa. This observation directly challenges the migrant syndrome or pessimistic perspective of migrant workers and their remittances. The construction of houses may not be productive investment as Lipton (1982) argues, but it must be noted that not all development is about investment, nor should or can all development be expressed in economic terms of profit and or financial gain.

Consequently, if the migrant teachers did not have a house before and now they do, or are in the process of building one, because of working in South Africa, this can be seen as promoting development in the context of provision of the shelter, a home of their own. Besides, for some migrant teachers, the construction of a house is an investment and the education of children in an elite private school is an investment in their child (ren)'s future: it cannot be regarded as encouraging consumerism in a negative sense. Therefore, the definition of the term investment in the context of the development impact of remittances is multi-dimensional and helps to illuminate the multi-dimensionality of the development process. To encapsulate aspects that are not strictly financial only, such as human and personal development, which forms the core of this paper, is appropriate. The provision of housing is indeed an important aspect of development (INSTRAW, 2007). Thus, it can be claimed that human development has been enhanced.
Furthermore, the use and impact of remittances should be judged against why the migrant moved in the first place (Parnwell, 1993). The results from this survey suggest that when the migrant teachers came to South Africa they unanimously (97\%) wanted, among other things, to improve their quality of life. This included buying and or building houses for their families in Zimbabwe. Since many of the migrant teachers who came to South Africa for this purpose have achieved this goal, it can be contended that human development for the migrant teachers has taken place. The development impact of remittances must not be judged against productive investments because, for many migrant teachers, such strictly economic investments and profits were not what they sought to achieve.

The migrant teachers have acquired a variety of assets ranging from houses to cars, furniture, electrical and other goods. Movable assets are accumulated in South Africa and sent to Zimbabwe for use and houses are constructed in Zimbabwe. The migrant teachers indicated that they would not have acquired these goods had they not migrated to South Africa. It must, however, be admitted that not all the migrant teachers have met their expectations. Some have not achieved anything or very little, due to low salaries, a short duration of stay in South Africa and the extent of their responsibility towards their extended family and other dependents. Generally those who had been in South Africa for less than two years, earned less than R4 000 a month and had many family members in Zimbabwe dependent on them, fell in the category of those who had achieved very little or nothing at all.

Linked to the aspect of asset accumulation by Zimbabwean migrant teachers, is the issue of savings. The questionnaire results revealed that $7 \mathrm{I}$ per cent of the respondents had savings. The average savings 
for an individual migrant teacher was about RI0 000, which at the exchange rate in 2009 was about US\$ I 300. Most migrant teachers in this position were extremely excited as they asserted that they could never lay claim to having such an amount of money before. The magnitude of this achievement should be seen against what their counterparts in Zimbabwe were earning, which was about US\$ 155 a month. This suggests a relatively healthy financial position which these Zimbabwean migrant teachers and their families are now enjoying. This is important especially considering that the migrant teachers argued that their counterparts in Zimbabwe had no savings whatsoever (since the banking sector had collapsed and was only beginning to recover slowly) and were fully dependent on the US \$ I55. Their being in South Africa had placed their own families in Zimbabwe in a better financial position because they could afford to send them money, goods and yet at the same time also save money in South Africa. It is instructive to note that the migrant teachers claimed that they were keeping their savings in South Africa so that, in the event of any huge financial need by their family in Zimbabwe, they would easily be able to meet their need.

\section{Access to health services and nutrition}

From a development point of view, a pleasing result was evidence that showed that there has been a huge and positive change in family nutrition and health status (Figure 4).

Figure 4: Changes in family nutrition and health in Zimbabwe

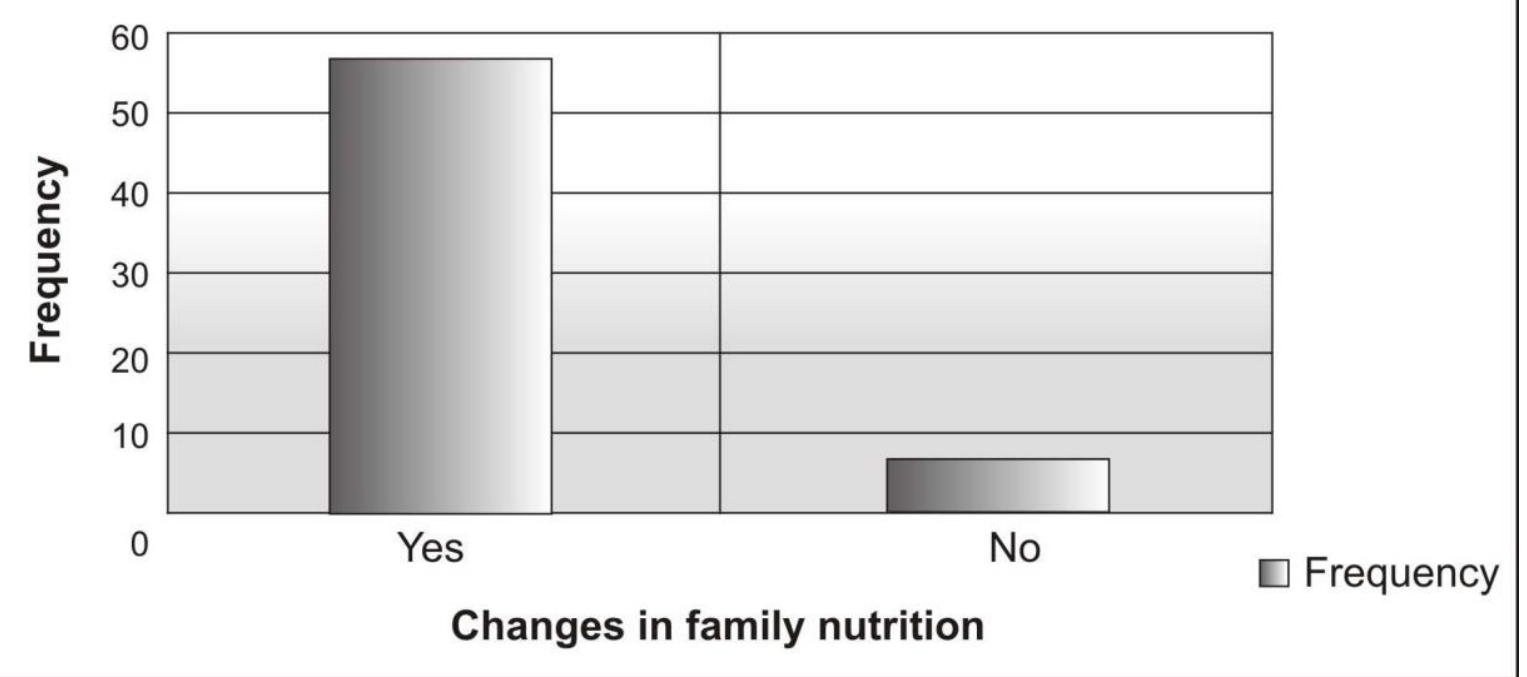

The questionnaire results revealed that the families of Zimbabwean migrant teachers who are in Zimbabwe, had access to a variety of nutritious foods. They indicated that before they migrated to South Africa it was a struggle to put even one meal on the table, but after migrating to South Africa their families can now afford at least three decent meals a day, breakfast, lunch and supper. The migrant teachers defined a decent meal as one that met the dietary needs of their family members. In addition, the migrant teachers claimed that, their families in Zimbabwe had a choice of what to eat and a variety of what they considered nutritious food were accessible to their families because they either sent the goods and food needed and/or sent money so that they could buy these goods.

Access to and improvement in health was measured in terms of the situation before migrating to South Africa. The overwhelming majority of Zimbabwean migrant teachers stated that the health delivery system in Zimbabwe had collapsed, state hospitals had lost a significant number of doctors and nurses and medical supplies were not only erratic but also sometimes not available. Their migration to South Africa had made it possible for them send money to their families to go to private doctors or attend private clinics which they could now afford, thereby guaranteeing sound and reliable medical care in spite of its cost.

Furthermore, because of the high cost of medication in Zimbabwe, the migrant teachers explained that in some cases and where possible, they were able to get the medication in South Africa and send it to their families in Zimbabwe. For this reason, the migrant teachers were adamant in their responses that the health situation of their families 
had significantly improved. In respect of family nutrition and health, the indices that measured improvements and/or development were: affording at least three decent meals a day, access to and affording a variety of nutritious foods; access to private doctors and clinics; affordability of medication; and the general capacity to meet most of the medical-related expenses. Before migrating to Zimbabwe, this would have been a dream, but that their families were living this dream, constituted an improvement in their welfare, itself a dimension of human development.

\section{Changes in quality of education}

The Zimbabwean migrant teachers in South Africa claimed that, when they and their colleagues in other parts of South Africa and the world left Zimbabwe, the result was that most schools in Zimbabwe actually had no teachers. Some even reported that some schools in the south-western parts of the country nearly closed down because there were cases where the only teacher available was the headmaster or headmistress. In such situations, no meaningful teaching and learning could take place, suggesting that the quality of education was extremely low. On these grounds it is no exaggeration to claim that when the majority of migrant teachers stated that due to their working in South Africa the quality of education of their children had fundamentally improved (Figure 5). The reason for this was that they could no longer rely on government schools. They sent money to their Zimbabwean families to pay for extra tuition and material resources that would improve the quality of teaching and learning of their children. It was possible for them to do this because they were now earning enough in South Africa to accommodate the extra expense involved.

Figure 5: Changes in quality of education

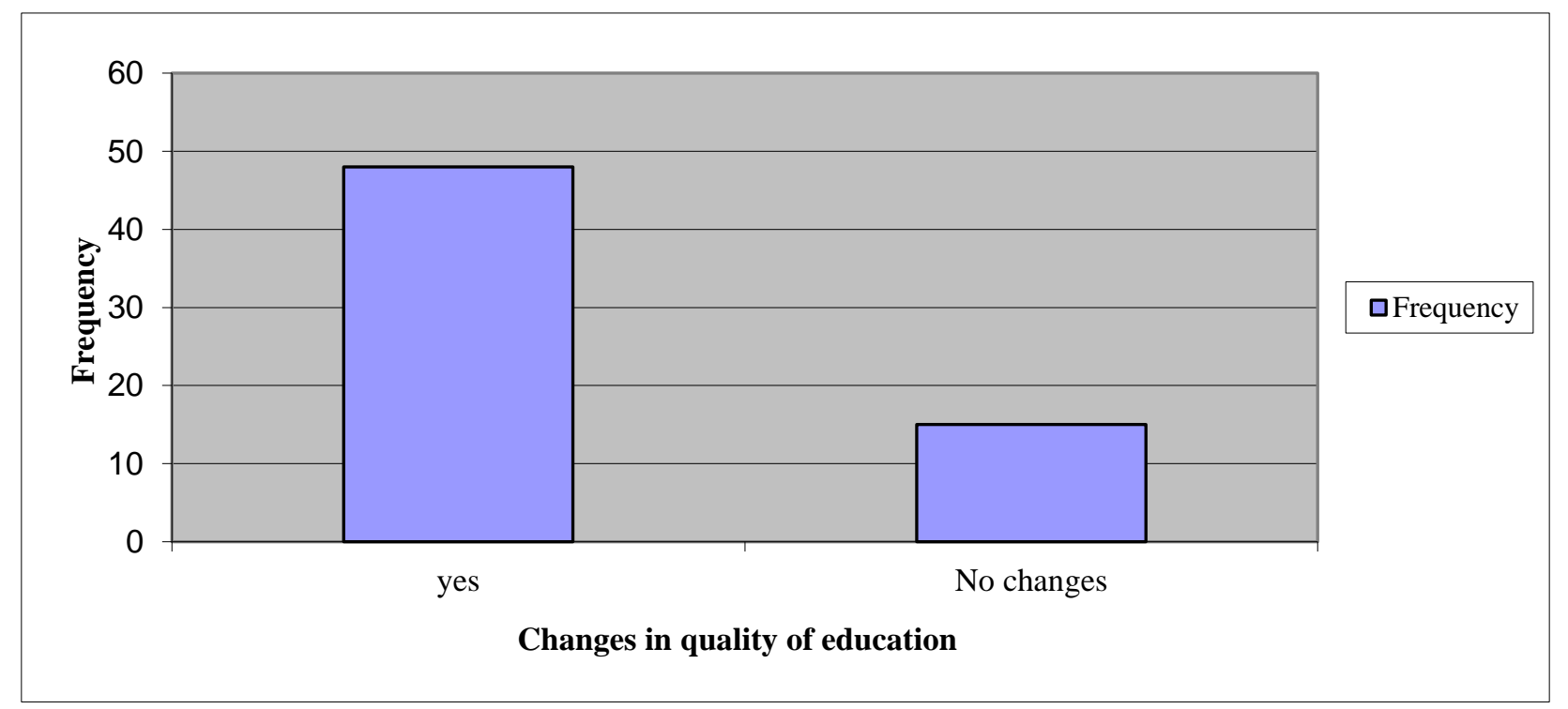

Regarding the 91 per cent of the migrant teachers who asserted that there had been an improvement in the quality of education, the indices of measurement for this notion were: access to and affordability of extra and private tuition (which meant that their children had good teaching-learning contact), affordability of extra textbooks and other equipment used by primary and secondary school-going children and sending children to private schools. Of those Zimbabwean migrant teachers who said the quality of their children's education had changed, $5 \mathrm{I}$ per cent had sent their children to private schools, where they had the choice to write either Zimbabwe Schools Examinations Council (ZIMSEC) or the Cambridge examinations, the of latter of which was highly favoured and preferred to the former for its alleged international recognition).

For these reasons, the migrant teachers were of the opinion that coming to South Africa fundamentally changed the quality of education of their children. While it is accepted that, it is difficult to measure the quality of education, the results suggest that the children of migrant teachers had better resources and services needed for teaching and learning to occur, than they would have had, had they stayed in Zimbabwe. Whether the concerned children utilised these and succeeded is another matter, but what is certain is that the fact of their 
parents working in South Africa improved the quality of their teaching and learning.

Finally, most migrants indicated that their lives had changed considerably. A clear majority (8I\%) said that they were now able to look after their children and their family properly and that life was back to normal for them and their families in Zimbabwe (Table 3).

Table 3: Changes in the lives of Zimbabwean migrant teachers and their families in Zimbabwe

\begin{tabular}{|l|l|}
\hline Change & Number \\
\hline $\begin{array}{l}\text { Can now look after my family and children, life is back to } \\
\text { normal, good diet and entertainment }\end{array}$ & $5 \mathrm{I}$ \\
\hline Feel the same-hand to mouth existence & 8 \\
\hline Not much change but better than in Zimbabwe & 4 \\
\hline Total & 63 \\
\hline
\end{tabular}

However, a few (19.1\%) said they felt the same as before they migrated to South Africa (Table 3), because the conditions of their families in Zimbabwe had not improved. In addition to this, 7I per cent of the migrant teachers participating in this survey said they had savings as opposed to 29 per cent who said they did not have any savings in South Africa. This is a good indication of the emergence of a promising situation for the migrant Zimbabwean teachers, because these savings are used to cater for their families in Zimbabwe, they are not meant for a life in South Africa.

Life stories of nine Zimbabwean migrant teachers In order to verify the trends and patterns established in the quantitative analysis, nine teachers were interviewed to tell their life stories. The names of the respondents as used in these interviews are imaginary to maintain their confidentiality.

\section{Respondent One}

Joshua teaches English and has been teaching in South Africa for four years and appears to be doing well and this is his story:

I am a forty-one year old man, born and grew up in Bulawayo. I am married and have two children who, together with my wife stay in Bulawayo, Zimbabwe. I was trained at the United College of Education where I graduated in 1997 with a Diploma in Education and went to study for a $B A$ in English and Communication with the Zimbabwe Open University and graduated in 2005. I taught in Zimbabwe for eight years from Januaryl998 to December 2005. Life was good during that time but towards the end of 2005 became bad because of the worsening economic situation in Zimbabwe. I moved to South Africa in December 2005 in search of a better life because the money that I was earning in
Zimbabwe was not enough to take care for my family. My stay in South Africa has improved the quality of life of my family because I can now look after my family sufficiently; they are not short of food like they were before I came to South Africa. My eldest son who is nine years old now attends Petra Primary School, a reputable private school in Bulawayo.

\section{Respondent Two}

Muleya is a thirty-eight year old man who was born in Beitbridge but grew up in Bulawayo. He is a qualified Science teacher having a Diploma in Education from Hillside Teachers' College in Bulawayo in 1995. From 2000-2003 he studied for a Bachelor in Education degree specialising in Biology at the University of Zimbabwe. He said:

I came to South Africa in 2007 as a result of a family decision for economic reasons, specifically the fact that I could not afford to feed my family. I am doing better in South Africa in terms of the fact that the quality of life for my family has improved, I can now afford to buy bread every day, and because before I came to South Africa I could not afford to buy bread daily, for my wife and children in Zimbabwe. Even with a low salary, my quality of life and that of my children has improved significantly compared to the situation when I was in Zimbabwe.

\section{Respondent Three}

Joseph Ngwenya is a thirty-six year old single man who was born and grew up in Bulawayo. He graduated with a Diploma in Education from Hillside Teachers' College in 2000 and taught in Zimbabwe for eight years before coming to South Africa in December 2008. He said:

I came to South Africa as a result of an individual decision which was influenced by the desire to 
support his family (mother and extended family). I came to South Africa in search of a better life. I was paid a very low and worthless salary in Zimbabwe, because I could not afford the basic necessities. Before I moved to South Africa I was earning an equivalent of R20 a month out of which I could not afford to pay rent, buy food and other necessities and for these reasons he came to South Africa. The salary which I get in South Africa is better because they I can afford to pay rent and buy food as well send my mother, siblings and extended family members groceries in Zimbabwe. South Africa is a good country and has many advantages because the economy is good and life is better and for this I would like to stay and teach in South Africa permanently. My life has improved tremendously because I can now take care of himself as compared to one situation in Zimbabwe when my total salary could not buy a tomato. There was a time in 2007, when I did not go and withdraw my salary because it was less than the cost of traveling to the banks and back home. I remember the black market conversion of my salary was about R5.00. Now I can fully support my mother, and my siblings and extended family in Zimbabwe with everything that they need."

\section{Respondent Four}

David, a thirty-two year old married man without children, was born and grew up in Chimanimani, Mutare, in the eastern part of Zimbabwe. He graduated in 2000 with a BSc Education (Physics) from Bindura University in Zimbabwe. He said:

I have bought a car, furniture and a host of electrical goods. I can also send groceries to Zimbabwe and a lot other things that the family in Zimbabwe needs. My life as well as nutrition, health and the education of children my extended family has also improved, because of my financial and material support, my family's children are going to better schools; they can afford extra tuition through private tutors. My social status has improved because I now own a car and can now save money.

\section{Respondent Five}

Patience is a forty year old married woman with three children. She qualified as a teacher from the United College of Education in 1994 and went on to study Special Education. She taught in Zimbabwe for twelve years and came to South Africa in 2005 for economic reasons because of the low salaries. She stated:

I have achieved a lot economically because I have bought a lot of household goods and furniture. My children are children are getting better education here in South Africa because in Zimbabwe there are no teachers. I send food and money to my mother and other family members in Zimbabwe and as a result the lives and nutrition of family members has improved, because of the contributions that I make. It makes me feel good that I have managed to change the lives of my family members.

\section{Respondent Six}

Dorcas is a fifty-two year old married woman with five children. She qualified as a primary school teacher from Mkoba Teachers College in Gweru and this is her story:

Coming to South Africa was a family decision because my husband is sixty years old and because of his age and the fact that the economic situation was bad in Zimbabwe we decided that I must come to South Africa. I feel that life has improved; the education of my children has improved because I pay the tuition. I send food and other groceries to Zimbabwe and as a result of this, the nutrition and health levels of her family have improved since they can eat what they want because it's available and affordable.

\section{Respondent Seven}

Nombulela is a forty year old single woman with an eighteen year old son. She said:

As a result of coming to South Africa I can now support my mother back in Zimbabwe; I have bought a residential stand in Zimbabwe and the construction process is in progress. My son is getting better education here in South Africa and is set to go to university and my family is Zimbabwe is benefitting a lot form my working in South Africa. Family nutrition and health in Zimbabwe has not significantly improved because I cannot afford to regularly send money and or food, but the situation is far better than if I had stayed in Zimbabwe.

\section{Respondent Eight}

Gugulethu is a thirty-four year old married woman with two children. She graduated with a BA degree and a Graduate Certificate in Education in 1996 and 2000 respectively. She taught in Zimbabwe for ten years before coming to South Africa at the end of 2007 to join her husband who was in South Africa. She said:

As a result of coming to South Africa together with my husband we are building a house which is nearing completion. I have also managed to buy household furniture. Due to my working in South Africa my life and that of my family has improved and in terms of the food they can get. I can afford 
whatever my children want and this has consequently improved the family health and nutrition. My eldest daughter attends an elite private school in Bulawayo. I would never have afforded the school fees in such school if I was in Zimbabwe and that is why coming to South Africa has most definitely economically and socially uplifted me and my family.

\section{Respondent Nine}

Samson is a thirty-five year old married man and a father of two. He was born and grew up in Masvingo in Zimbabwe and states that;

The economic situation in Zimbabwe was bad, I could not afford food and this coincided with the fact that there was a need for Mathematics and Science teachers in South Africa and I used this opportunity to come to South Africa because it has a strong currency as compared to the Zimbabwean dollar. I came to South Africa so as to work and feed my family; I could no longer do so in Zimbabwe. I could not afford to buy clothes and shoes let alone food. I can do all this now. My life and that of my family has been transformed from a hopeless to a bright future. I am happy working in South Africa because I have managed to build a four roomed house in rural Masvingo. I have also bought a car, something which I could not dream of while in Zimbabwe. There is a huge improvement in the quality of life of family members because I support them with food and groceries back in Zimbabwe.

\section{Discussion of qualitative results}

From the qualitative interviews it became clear that the quality of life of the migrant teachers' immediate and extended families had improved significantly in terms of education, nutrition and health services because of the remittances that were being sent to Zimbabwe. Some of the migrants $(75 \%)$ had acquired a host of assets as a result of working in South Africa. This indeed confirms that human development had indeed taken place. One respondent in the in-depth qualitative interviews indicated that while in Zimbabwe, an entire salary could not buy a tomato, declaring that working in South Africa had uplifted them as they could now afford all the basic necessities of life. If it was about buying tomatoes, they could now afford all tomatoes on a big farm in Zimbabwe, which they could not do while they were working in Zimbabwe. Failing to buy a tomato on a month's salary for a school teacher is a most graphic illustration of poverty that had penetrated the lives of Zimbabwean teachers. It reveals that working in South Africa has enabled them to overcome their plight. Moreover it shows the development impact of remittances that make financial resources available to family members whose financial resources were seriously dwindling in Zimbabwe.

Synthesis of the quantitative and qualitative data analysis

The migration of Zimbabwean teachers to South Africa and the consequent remittance tendency has benefitted the well-being of their families. In other words, there has been a positive change in the welfare of the families of migrant teachers as a result of migration to South Africa. In particular the migrants' financial status has been enhanced through their savings. This demonstrates that remittances have had a development impact in respect of changing the lives of the families in Zimbabwe of migrant teachers who work in South Africa. The view that remittances bring development at least at household level is thus sustained. Furthermore, positive changes in family education, health and nutrition make the development impact on the migrant sending households and/or families money very clear. In turn, it demonstrates that transient poverty has been addressed. This is especially significant in view of the fact that these families did not have any choices with regard to education, health and nutrition. Before migrating to South Africa, their families in Zimbabwe did not have a choice of extra and private tuition or indeed attending private schools. Neither could they afford at least three decent meals a day, because whatever food was available was minimal and barely kept body and soul together. At present, this seems now like remote history because working in South Africa has financially empowered the migrant teachers in that they have allowed for the availability of more choices in life for their immediate and extended families in Zimbabwe. This provides positive evidence of the definite impact of remittances at the household level that allows for an improved quality of life.

However, it is important to add that this significant impact of remittances on the families of migrant teachers in Zimbabwe could be because the economic collapse in Zimbabwe had reduced many people to abject levels of poverty, such that even the smallest amount of remittances made a positive difference. Therefore, it is also possible to theorise that in scenarios where people exist in a cesspool of poverty and acute deprivation, remittances will always have a positive human development impact. In this regard, the findings of this paper could be regarded as context specific. It can thus be stated that in situations where there is total collapse of the economy and shattering of livelihood bases, remittances definitely achieve a positive human 
development impact. This seems to be the case in the Zimbabwean migrant teachers in South Africa and their families in Zimbabwe.

There is a convergence in the findings from both the quantitative and qualitative in- depth interviews, in that as a result of the economic meltdown in Zimbabwe, the Zimbabwean teachers and their families lived in obscene deprivation and the migration of the Zimbabwean teachers to South Africa changed this. Consequently the migration of Zimbabwean teachers to South Africa and their resultant development impact can be equated to saving their families from certain death from starvation and famine or both, rescuing their children from a hopeless teacher-less learning environment, restoration of failed medical protection and financial liquidity and other comforts and needs of life such as various household items and houses respectively.

\section{Conclusion}

The data presented in this paper suggests that remittances sent to Zimbabwe by migrant teachers had a positive developmental impact. This can be ascribed to increased asset accumulation and home ownership and access to education. Health status has also improved, so have nutrition, income disposal and the general welfare of the people directly or indirectly dependent on the Zimbabwean migrant teachers. The families in Zimbabwe of the migrant teachers studied have many more and wider choices in life, their welfare has been uplifted and they live well above the poverty line as a result of working in South Africa. It is therefore possible to hypothesize that those professional migrant workers who are gainfully employed in the host country and have ties with their areas of origin have improved their level of development.

The results also suggest that avenues for further research could include investigating such issues as the impact of remittances at community and national level in a country like Zimbabwe that needs much more attention being paid to development and reconstruction after the severe and stormy effects of politico-economic collapse that left ordinary people's livelihoods in smithereens. Such research may help illuminate the power of remittances and how these remittances kept a country going at a time when the government could not pay workers, living salaries such that the latter were rendered economically powerless by the debilitating economic problems and inflation that afflicted the country from about the year 2000 and reached its all-time low in about 20072008.

\section{References}

Adepoju, A. (2003) "Leading Issues in International Migration in Sub-Saharan Africa" Views on Migration in Sub-Saharan Africa: Proceedings of an African Migration Alliance Workshop, C, Cross, D. Gelderblom, N. Roux, and J. Mafukidze (eds), Cape Town, HRSC Press.

Bloor, M. (1997) "Techniques of Validation in Qualitative Research: A Critical Commentary". Contexts and Methods in Qualitative Research, G. Miller, and R. Dingwall (eds), London: Sage Publications.

Campbell, E K. (2006) "Reflections on Illegal Immigration in Botswana and South Africa", African Population Studies Journal, 2I (2), I-23.

Chami, R.F. and Samir, J. (2005) "Are migrant remittance flows a source of capital for development?" IMF Staff Papers, ABI/IMFORM Global.

Chimhowu, A. Piese. J. and Pinder, C. (2005) "The Socio-Economic Impact of Remittances on Poverty Reduction", Remittances: Development Impact and Future Prospects, S.M. Maimbo, and D. Ratha (eds), Washington DC, The International Bank for Reconstruction and Development/World Bank.

Cresswell, J.W. (1994) Research Design: Qualitative and Quantitative Approaches, London, Sage Publications.

Creswell, J.W. and Plano Clark, V.L. (2007) Designing and Conducting Mixed methods Research, Thousand Oaks, Sage Publications.

Creswell, J.H. and Plano Clark, V.L. (20I I) Designing and Conducting Mixed Methods Research, Los Angeles, London, New Dehli, Singapore, Washington DC, Sage Publications.

Creswell, J.H. (2009) Research Design: Qualitative, Quantitative and Mixed Method Approaches, Los Angeles, London, New Delhi, Singapore, Washington DC, Sage Publications.

Crush, J. and McDonald, D. (200I) "Introduction to Special Issue: Evaluating South African Immigration Policy after Apartheid", Africa Today, 48, (3), I13.

Crush, J. (2002) "The Global Raiders: Nationalism, Globalization and the South African Brain Drain", Journal of International Affairs, 56, (I).

Crush, J. Williams, V. and Peberdy, S. (2005) "Migration in Southern Africa" Paper prepared for policy analysis and research programme of the Global Commission on International Migration,September2005.http://www.iom.int/jahi a/webdav/site/myjahiasite/shared/shared/mainsite/ policy_and_research/gcim/rs/RS7 
Crush, J. Campbell, E. Green, T. Nangulah, S. and Simelane, H. (2006) "States of Vulnerability: The Future Brain Drain to South Africa", Migration Policy Series, No. 42, Cape Town, IDASA.

Crush, J. and Pendleton, W. (2007) "Mapping Hostilities: The Geography of Xenophobia in South Africa", South African Geographical Journal, 89 (I), 64-82.

Davids, N. (2009) "Third of South African Teachers Lack Right Qualifications", The Sunday Times, I November 2009.

De Haas, H. (2008) "Migration and Development: A Theoretical Perspective", Working Paper 9, University of Oxford, International Migration Institute.

De La Hunt, L.N. (1998) "Refugees and Immigration Law in South Africa", Beyond Control: Immigration and Human Rights in a Democratic South Africa, J, Crush (ed), Cape Town, IDASA.

Govender, P. (2008), "Wanted: 94000 teachers, urgently", The Sunday Times, 23 November 2008.

INSTRAW, (2007) Migration and Development: Gender, Remittances and Development, Working Paper 3, New York, United Nations International Research and Training Institute for the Advancement of Women.

Jevees, A. (1985) Migrant Labour in South Africa's Mining Economy: The Struggle for Gold Mines' Labour Supply-1890-1920, Johannesburg, Witwatersrand University Press.

Kapur, D. (2005) "Remittances: The New Development Mantra", Remittances: Development Impact and Future Prospects, S.M. Maimbo, and D. Ratha, (eds),Washington DC, The International Bank for Reconstruction and Development/World Bank.

Keeley, C.B. (1989) "Remittances from Labour Migration: Evaluation, Performance and Implications", International Migration Review, 23 (3), 500-525.

Kitchin, R. and Tate,N. J. (2000) Conducting Research in Human Geography: Theory, Methodology and Practice. London: Pearson.

Lipton, M. (1982) "Migration from rural areas of poor countries: the impact on rural productivity and income distribution", Migration and the Labour Market in Developing Countries, R. Sabot (ed), Colorado: Westview Press.

Manghezi, A. (1998) "Legacies of Labour Migration from Southern Mozambique to South Africa", Labour and Migration in Southern Africa, L. Sachikonye, (ed), Harare: Sapes Trust.

Maimbo, M.S. and Ratha, D. (2005). Remittances: Development Impacts and Future Prospects. Washington DC, The World Bank
Maphosa, F. (2005) "The Impact of Remittances from Zimbabweans Working in South Africa on Rural Livelihoods in the Southern Districts of Zimbabwe" Forced Migration Working Paper Series \# 14, Forced Migration Studies Programme, University of Witwatersrand.

Maphosa, F. (2007) "Remittances and development: the impact of migration to South Africa on rural livelihoods in Southern Zimbabwe", Development Southern Africa, 24 (I), I23-I 36.

Maphosa, F. (2009), "Rural livelihoods in Zimbabwe: impact of remittances from South Africa", Monograph Series, Dakar, CODESRIA.

Mavhunga, C. (2012) Zimbabwe teachers strike for more pay. http://www.news24.com/.

Mills, G. (1998) "Lessons unlearned: South Africa's foreign policy- from isolation to respectability", South Africa in Southern Africa: Reconfiguring the Region, D. Simon (ed), Oxford, James Currey.

Ncube, G and Gómez, G. (201 I). Local economic development and migrant remittances in rural Zimbabwe: building on sand or solid ground? Working Paper No. 523, Institute of Social Studies,

Netherlands.https://www.researchgate.net/public ation/24I755564_Local_economic_development and_migrant_remittances_in_rural_Zimbabwe_bu ilding on sand or solid ground

Omer, A., and Koury, E.L. (2005) "Regulation and supervision in a vacuum: the story of the Somali remittance factor", Remittances: Development Impact and Future Prospects, S.M Maimbo and D. Ratha (eds), Washington DC, The International Bank for Reconstruction and Development/World Bank.

Oucho, J. (2005) "Cross Border Migration and Regional Initiatives in Managing Migration in Southern Africa", Migration in South and Southern Africa: Dynamics and Determinant, P. Kok, D. Gelderblom, J. Oucho, and J. van Zyl (eds), Cape Town, HSRC Press.

Parnwell, M. (1993) Population Movements in the Third World. London: Routledge.

Pendleton, W. Crush, J. Campbell, E. Green, T. Simelane, H. Tevera, D. and De Vletter, F. (2006) "Migration, Remittances, and Development in Southern Africa”, Migration Policy Series, No. 44, Cape Town, IDASA.

Ratha, D. and Shaw, W. (2007a) 'Causes of SouthSouth Migration and its Effects', http://www.migration information.org/feature/display.cfm?ID $=647$.

Ratha, D. and Shaw, W. (2007b) South-South Migration and Remittances. Development Prospects Group, World Bank. 
Sander, C. and Maimbo, S.M. (2005) "Migrant remittances in Africa: a regional perspective", Remittances: Development Impact and Future Prospects, S.M Maimbo and D. Ratha, (eds), Washington DC, The International Bank for Reconstruction and Development/World Bank.

Sibanda, N. (2009) "Teachers vow to strike", The Zimbabwean Star, 29 July-04 August 2009.

Tashakkori, A. and Teddlie, C. (2003) Handling mixed methods in social and behavioural sciences, Thousand Oaks, Sage Publications.

Teddlie, C. and Tashakkori, A. (2009) Foundations of mixed methods research: integrating quantitative and qualitative approaches in the social and behavioural Sciences, Los Angeles, London, New Delhi, Singapore, Washington DC, Sage Publications.

Tevera, D. and Chikanda, A. (2009) "Migrant remittances and household survival in Zimbabwe", Migration Policy Brief No 5I, Southern African Migration Project, Cape Town: IDASA.

Von Burgsdorff, D. (20/2) "Strangling the lifeline: an analysis of remittance flows from South Africa to Zimbabwe". A report compiled by people against suffering, oppression and poverty (PASSOP).

World Migration Report, (2000) Geneva: International Organization for Migration and United Nations. 